\title{
'Maak die wêreld nie tot bespotting nie': 'n Herwaardering van die filosofiese aspekte in Mechtild von Magdeburg se Das fliessende Licht der Gottheit (1250)
}

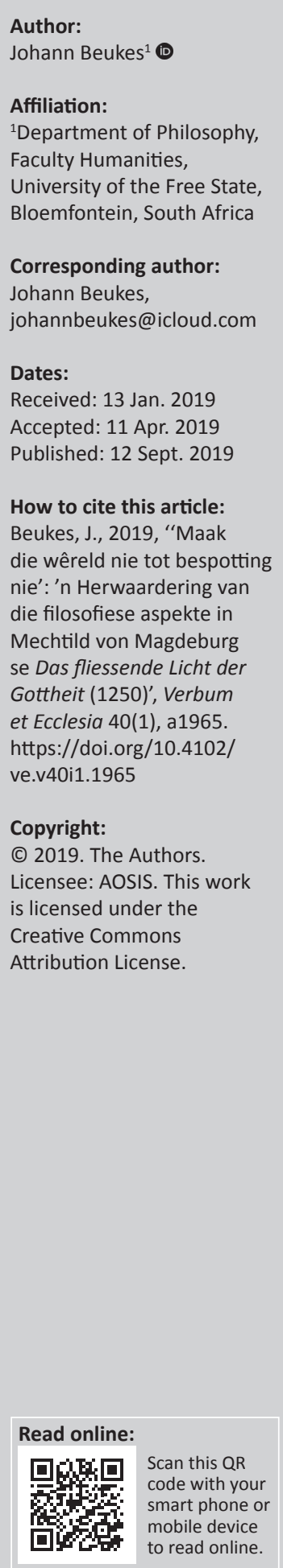

'Do not ridicule the world': A reappraisal of the philosophical aspects in Mechtild of Magdeburg's Das fließende Licht der Gottheit (1250). This article provides a reappraisal of the philosophical aspects in Mechtild von Magdeburg's (ca. 1207-1282) Das fließende Licht der Gottheit, written in 1250 and found in 1860, only then to be edited in modern German. The article argues that Mechtild's philosophical output constitutes a unique counter-cultural reaction from the 13th century. Her philosophical perspectives are characterised and represented by a solemn dictum for a 13th century nun (albeit a beguine), 'do not ridicule the world'), which amounts to an intellectual engagement that takes the world seriously on a constant basis. Her emphasis on the union of the human and the Godhead, the primary role she attributes to experience in the acquisition of knowledge and her ethical interest in the 'Other' in a fragile world, stand to serve her deepest impression that love is the primary principle of both God and creation. Showing little interest in essentialist or causal analyses, with the exception of the principle of love, and with little in common with her early-scholastic contemporaries in their intellectual, scholastic refinements of the life-world system, she nevertheless exerted an influence on the mystical trajectories of the later Middle Ages, especially in the German tradition of Meister Eckhart.

Intradisciplinary and/or interdisciplinary implications: As a millennium-long discourse, Medieval philosophy functions in a Venn diagrammatical relationship with Medieval history, Church history, patristics and philosophy of religion. Whenever 'mainstream' or 'canonised' Medieval philosophy is impacted from the niche research, it may well have implications that these closely related disciplines could take note of.

Keywords: Mechtild von Magdeburg; Das fließende Licht der Gottheit; a metaphysics and cosmology of movement; neoplatonic emanation; the triadic relation of the soul and the senses.

\section{Inleiding: Mechtild, 'n sonderlinge bedelnon}

In 1860 word die kopie van 'n teks, getitel Das fließende Licht der Gottheit, eenkant en weggesteek in 'n Duitse kloosterruïne gevind. Dit was ' $n$ werk, geskryf in die Duitse volkstaal en nie in Latyn nie, deur 'n vrou wat haar lewe en werk as 'n Christelike mistikus met besondere filosofiese aanvoeling en erudisie beskryf. Die werk is telkens daarna deur Duitse literêre kritici, filosowe en teoloë beskryf as een van die eerste voorbeelde van die Duitse mistieke beweging, in die 14de eeu tot 'n hoogtepunt gebring deur Meister Eckhart (ca. 1260-1328; Gibson 1989:121-2). Die teks is oorspronklik in Middellaagduits aangebied en het behoue gebly in Middelhoogduits en Latynse vertalings, totdat dit in die 19 de eeu in moderne Duits vertaal is.

Die skrywer van hierdie teks (Mechtild 1980; van hier fLG) bied haarself aan as Mechtild, ${ }^{1}$ gebore ${ }^{2}$ in die eerste dekade van die 13de eeu en afkomstig vanuit die relatiewe jong en ontwikkelende Middeleeuse dorp Magdeburg. Vanuit die teks, met betrekking tot die aanbod van 'n deeglike kennis van filosofie, teologie en die Bybelse tekste self, is dit duidelik dat die skrywer akademies hoogs opgevoed was en waarskynlik familiebande met die laer-Saksiese adelstand gehad het. Hoewel sy haarself as 'ongeleerd' bestempel omdat sy nie Latyn kon lees of skryf nie, was haar

1.Ook as Mechthild en later as St Mechtildis gespel. Hierdie bespreking is gebaseer op' $n$ analise en sintese van die volgende primêre teks van Mechtild (1980, 1991), asook in besonder die volgende sekondêre tekste: Bynum (1984:228-34); Dickens (2009:71-86); Dronke (1984:202-28); Eliass (1995:54-64); Franklin (1978:35-170); Gibson (1989:115-40), Howard (1984:153-63) en McGowin (2011:607-22).

2.Die volgende bio-afkortings, soos gangbaar in die Middeleeuse navorsing, word gebruik: ca. (circa, ongeveer in die tyd van); fl. (floruit, floreer of hoogtepunt bereik); g. (gebore) en d. (sterfdatum). 
Duitse taalgebruik elegant en foutloos. Soos haar vroulike Duitse voorganger Hildegard (sien Beukes 2019c), het Mechtild van jongs af visioene ${ }^{3}$ van God beleef, waarvan sy die eerste insident onthou toe sy 12 jaar oud was. Op die ouderdom van 22 besluit sy om haar lewe as non in diens van God te wy, maar van meet af aan buite die gevestigde ordes, waarteen sy krities gekant was, veral op grond van wat sy waargeneem het as, enersyds die hebsug en akademiese voortvarendheid van die vroeë skolastiese ${ }^{4}$ monnike en die andersyds na binne gekeerdheid van nonne, in sowel die Cistersiaanse, Dominikaanse en Franciskaanse ordes (Eliass 1995:86). ${ }^{5}$

Sy besluit daarom om nie aansoek te doen om as 'n nuweling in 'n nabye dogterklooster of een van die groter abdye in Duitsland toegelaat te word, waar sy van verdere akademiese opleiding verseker kon wees en as non georden kon word nie, maar om 'n bedelnon te word. Die woord bedel is in Afrikaans betreklik pejoratief en skakel maklik met opvattinge wat boemelary en luiheid impliseer. Allermins is dit wat die bedelordes was: Die begyne was godsdienstige groepe in die Middeleeue wat hulleself streng geslagtelik en grotendeels in terme van die gevestigde kloosterstrukture georganiseer het, sonder dat enige lid van die betrokke orde bindende geloftes moes aflê ten opsigte van ' $n$ lewe in selibaat en om gestroop te word van bestaande of toekomstige individuele eiendom (wat juis die bron van inkomste van die meerderheid van kerklik gesanksioneerde ordes was; Eckenstein 2010:328-53). Bedelmonnike en bedelnonne was vry om te kom en te gaan, maar moes lojaal teenoor die betrokke bedelorde bly. Hulle was dus ook vry om die bedelorde permanent te verlaat sonder enige strafsanksie, maar kon nie na die spesifieke bedelorde terugkeer wanneer dit eenmaal verlaat is nie (Lewis 1989:24).

Tegnies het die bedelordes dus nie gebedel nie, maar was hulle wel vir die daaglikse onderhoud afhanklik van die barmhartigheid van die betrokke gemeenskap waarin hulle hul bevind het. In ruil het hulle in die gemeenskap versorgingswerk gedoen, wat ingesluit het die versorging van siekes, gebreklikes, bejaardes en weeskinders. Trouens, teen die helfte van die 13de eeu was die meerderheid verpleegsters in Duitsland bedelnonne (Eckelstein 2010:330). Bedelnonne was egter sosiaal blootgestel: juis omdat die bedelorde nie

3.Mechtild se visioene en poësie is nie soos dié van Hildegard met haar filosofiese uitset verweef nie en moet op ' $n$ ander vlak geëksegetiseer word. Slegs die filosofiese aspekte in Das fließende Licht der Gottheit geniet dus hier aandag.

4.Oor periodisering in die Middeleeuse filosofie, sien Beukes (2019a, 2019b, 2019c 2019d). My sesdelige periodisering van Middeleeuse filosofie kom in kort op die volgende neer: (1) Die post-Romeinse periode (vyfde tot sewende eeue [410 \{Alaricus I en die eerste barbaarse inval in Rome\} tot 668 \{d. Konstans II\}], met Augustinus [354-430] en Boethius [480-524] as die belangrikste filosofiese Augustinus [354-430] en Boethius $[480-524]$ as die belangrikste filosofiese
eksponente); (2) Die Karolingiese periode (agste en negende eeue [742 \{g. Karel I\} tot 877 \{d. Eriugena\}], met Alcuin [730-804] en Eriugena [815-877] as die belangrikste Latyns-Westerse geleiers van die Karolingiese Renaissance, me inbegrip van die opkoms van Arabiese filosofie in die Ooste en Spanje); (3) Die post Karolingiese periode (9de tot $12 \mathrm{de}$ eeue [877 \{d. Eriugena\} tot 1088 \{aanvang van die kruistogte en die opkoms van die vroegste universiteitswese\}], met Anselmus [1033-1109] en Abelardus [1079-1142] as die mees gevolgryke onder die LatynsWesterse denkers wat sou baat by die rehabilitering van die antieke erfenis in die Karolingiese Renaissance); (4) Die vroeë skolastiese periode (11de tot 13de eeue [1088 \{stigting van die Universiteit van Bologne, die eerste Europese universiteit\} to [1088 \{stigting van die Universiteit van Bologne, die eerste Europese universiteit\} to 1225 \{g. Aquinas\}]); (5) Die hoë skolastiese periode (13de tot 14de eeue [1225 \{g. Aquinas\} tot 1349 \{d. Ockham\}, met Aquinas, Duns Skotus en Ockham as die beroemdstes onder die hoë skolastici]); (6) Die post-skolastiese periode (14de tot
15 de eeue [1349 \{d. Ockham\} tot 1464 \{d. Kusa\}]).

5.Vir 'n oorsig oor Mechtild se kultuurkritiese verset teen die kloosterwese en die Duitse biskopdomme van die 13de eeu, sien Eliass (1995:75-101). onder die toesig van die plaaslike klooster en provinsiale biskop gefunksioneer het nie, kon hulle nie op die soort beskerming aanspraak maak wat geordende nonne en monnike binne die kloosters en abdye geniet het nie. Juis hulle vrygeestigheid het hulle ook oopgestel vir voortdurende aanklagte van kettery (veral ten opsigte van wat beskou is as 'n antroposentriese teologie en'n humanistiese mensebeskouing), seksuele immoraliteit (wat sporadies plaasgevind het binne die konteks van selfde geslag, maar binne die bedelordes allermins algemeen was) en openbare bedelary (wat wel voorgekom het, maar slegs wanneer die plaaslike gemeenskap die betrokke begyne versaak het; McDonnell 1954:45). In 1311 is die beweging van bedelordes by die konsilie van Vienne onder leiding van pous Clemens V (pous vanaf 1305-1314) finaal veroordeel (dieselfdekonsilie het pouslike ondersteuning van die gevierde Ridders van die Tempelorde teruggetrek) en die bedelordes is daarna verban en ontbind (Bynum 1984:175). Dit was egter ruim drie dekades na Mechtild se afsterwe.

Die onafhanklike bedelordes, blootgestel soos wat hulle was, het Mechtild se vrye gees soos 'n handskoen gepas en sy sou vir die volgende 40 jaar, totdat sy waarskynlik net oor 50 jaar oud was, ' $n$ bedelnon bly. In 1250 begin sy om haar lewe as bedelnon op skrif te stel en die enorme verguising te boekstaaf wat sy en ander bedelnonne moes verduur, maar veral ook sistematies rekenskap te gee van haar filosofiese en teologiese beskouinge, juis as mistikus. In die werk spreek sy skerp kritiek uit teen korrupsie in die kerk en die hebsug van die monnike in sommige kloosters en abdye. Die kritiek sou natuurlik heftig teengegaan word en sy is by meer as een geleentheid fisiek aangerand. Uiteindelik sou sy die bedelorde in Magdeburg weens 'n verswakte liggaam en bedroefde gees moes verlaat om wel toegang te vind in ' $n$ klooster, waar sy as blinde in haar latere jare versorg sou word (Bynum 1984:173-86; Gibson 1989:132[1]).

Mechtild betree in ongeveer 1260 die klooster in Hefta, wat onder leiding van die abdis Gertrude van Hackeborn (ca. $1220-1291$ ) in daardie stadium as 'n sentrum van geleerdheid, onderrig en versorging vir vroue - hoewel slegs as geordende nonne - ontwikkel het (Bynum 1984:175; Eliass 1995:86-97). Rondom 1282 sterf hierdie vrye gees in Hefta, uiteindelik wel as non georden, omring deur slegs enkele vriendinne. Heinrich von Halle sou haar werk, wat sy self met die hand geskryf en wat uiteindelik sewe afsonderlike boeke beslaan het, na haar dood in Latyn vertaal, ter wille van verhoogde toeganklikheid buite Duitsland. In die latere Middeleeue het die gerug lank die ronde gedoen dat Dante (1265-1321) toegang tot hierdie vertaling gehad het en dat Matelda in sy Purgatorio op die persoon van Mechtild geskoei was, maar dit is in die moderne navorsing telkens as 'n onwaarskynlike koppeling uitgewys (Gibson 1989:117).

\section{Beweging as metafisiese en kosmologiese kernbegrip by Mechtild}

Mechtild werk filosofies veel meer diskursief as haar Franse voorganger in die Middeleeuse vroulike tradisie, Héloïse 
d'Argenteuil (ca. 1100-1164; sien Beukes 2019b) en skerper op die kultuurkritiese spoor van haar Duitse voorganger Hildegard von Bingen (1098-1179; sien Beukes 2019c). Met 'meer diskursief' word bedoel dat Mechtild 'n wye verskeidenheid van filosofiese temas binne haar uitset aanbied - anders as Héloïse, wat haar tot enkele temas beperk het. Ons tref egter 'n heeltemal uniek filosofiese leitmotiv by Mechtild aan, in terme van haar aanbod van beweging as ' $n$ metafisiese en kosmologiese kernbegrip, met geen presedent tot in daardie stadium in die Middeleeue nie. ${ }^{6}$ In by verre die grootste deel van die Hellenistiese en skolastiese denke is beweging met onstabiliteit geassosieer en negatief gewaardeer, terwyl die statiese en onveranderlike - die vroeë skolastici het graag van 'hoe digter, hoe ligter' gepraat - met stabiliteit en met God self geassosieer is.

In die Neoplatonisme word daar wel aan die hand van afstygende emanasie 'n sin vir 'beweging' veronderstel.? Mechtild se sin vir beweging, waaruit die 'vlietende' (fließende) lig van die Godheid blyk, vind aansluiting by Pseudo-Dionisius (ca.500) se Neoplatoniese vertrekpunt dat God 'anderkant syn' (hyperousios) is. ${ }^{8}$ Dit beteken dat God die basis vir alle synsvorme is, maar self nie-syn of 'n synsvorm is nie, en daarom absoluut onkenbaar en onverwoordbaar is. God is die Een, wat die eerste beginsel van die werklikheid is, anderkant syn en kennis, met die gelyklopende leerstelling dat 'om te wees, is om verstaanbaar te wees'. Dit bevestig dat wat ook al is, bedinkbaar is, verstaanbaar vir die verstand. Dit sou onmoontlik wees om 'n syn te postuleer wat nie bedink kan word nie, aangesien so 'n postulering reeds aankom op ' $n$ bedenking van die syn. Verstaanbaarheid, dit wat deur die verstand begryp kan word, is in hierdie sin die wesenlike betekenis van syn. Syn is daarom in Neoplatoniese sin duidelik en tegelyk begrensd; alleen 'n definitiewe en begrensde 'dit' kan deur die verstand begryp word. Enige syn bestaan daarom in die gedetermineerde totaliteit van die eienskappe of attribute van daardie syn, waarom dit is wat dit is, en juis daarom begryplik is. Wanneer Dionisius God as hyperousios postuleer, beteken dit nie dat oor God slegs in terme van negatiewe predikate gepraat kan word nie; met ander woorde, dat slegs negatief gepostuleer kan word dat God 'nie is nie' of dat God 'onkenbaar is' - omrede die negatiefstelling of negasie steeds 'n denkhandelende aktiwiteit is en as sodanig God steeds, hoewel in die negatief, konseptualiseer. In daardie sin is daar geen korrektiewe verskil tussen God 'is' en God 'is nie' - om God se bestaan of enige wesenseienskap van God te negeer, beteken om God steeds as 'n gekonseptualiseerde objek te hanteer; hetsy enersyds in besit van of andersyds ontdaan van bepaalde wesenseienskappe. Om te postuleer 'God is onkenbaar' beteken effektief om God te identifiseer as 'n

6.Die aard van hierdie artikel is enersyds oorsigtelik, in die sin dat grondig aanda. gegee word aan die relevante intellektuele geskiedenis. Die artikel is andersyds analities en sinteties, bedoelende dat die primêre teks so selfstandig moontlik gelees is sonder sekondêre teksbegeleiding of vertalings, waarna die sekondêre tekste geraadpleeg en getoets word aan my lesing, om tot ' $n$ koherente sintese te kom.

7.Die begrip emanasie dui Plotinus se bedoeling aan met die afstygende produksie van Syn vanuit die Een na die Verstand na die Siel en die laer dinge.

8.Pseudo-Dionisius (1990: De Divinis nominibus 14,593A). Die lengte van verwysings volgens Harvard na Dionisius werk steurend in op die vloei van die teks. Daarom word verwysings na Dionisius se tekste per voetnoot hanteer. onkenbare wese - en maak dus wel aanspraak op kennis van God, hoe minimaal ook al. Daarom stel Dionisius dat God 'anderkant elke negasie en affirmasie' ${ }^{\prime}$ is. God is nie bloot onverwoordbaar en onkenbaar nie, maar is 'anderkant onverwoordbaarheid en onkenbaarheid'. Die vraag ontstaan of daar vanuit hierdie Neoplatoniese gerigtheid hoegenaamd oor God gedink en gepraat kan word, anders as om terug te trek in stilwording. Dionisius se antwoord is dat ons wel oor God kan praat, in die sin dat ons God kan benaam of kan ken vanuit die geskape dinge (dit is alle syn), as juis die oorsaak van daardie dinge of syn. ${ }^{10}$ Op die oog af beteken die aanduiding 'oorsaak' wel weer ' $n$ indentifisering van God as syn, dan natuurlik begrens en verstaanbaar. Dionisius gebruik die begrip 'oorsaak' egter bepaald Neoplatonies: Aangesien 'is' of 'om te wees' beteken om determineerbaar te wees, is enige wese of syn vir die bestaan daarvan afhanklik van die gedetermineerdheid daarvan, sodat juis die gedetermineerdheid daarvan die oorsaak van die syn kan wees. God is die Skepper van alle dinge, as die konstituerende determineerder van alle dinge, wat elke ding determineer om te wees deur dit te maak 'wat dit is'. God is sodoende die 'Synheid van alle Syndes, sonder dat God self Syn is'. ${ }^{11}$ Dit alles dui op ' $n$ metafisika van vervlietendheid, tegelyk 'is' en 'is nie'.

Mechtild het met haar sin vir beweging hierdie tegelyk 'is' en 'is nie' in gedagte; 'n beweging, maar so vervlietend, dat dit nouliks as beweging herken kan word. Sy begin haar verwerking van dié Neoplatoniese sin vir beweging aanvanklik met die vier elemente: die filosofiese basis van haar denke sou trouens herlei kon word na haar herhaalde verwysings na die vier elemente van aarde, lug, vuur en water (Franklin 1978:35; Gibson 1989:122). Hierdie vier elemente word deur Mechtild aaneengeskakel om die menslike en die Goddelike in verhouding te bring. Die antitetiese spanning tussen hierdie elemente word oorkom deur die transformasie van die elemente (byvoorbeeld water, ys en lug). Binne hierdie vloeibaarheid van die elemente word die menslike bestaan na liggaam en siel aangebied as 'n mikrokosmos van die grootste geheel, die kosmos self. As mikrokosmos is die mens inderdaad imago Dei, geskape na die beeld van God, wat opvallend vir Mechtild (soos vir die Switserse teoloog Emil Brunner in die 20ste eeu) op 'n relasionele kwaliteit of verhoudingsmoontlikheid tussen God en mens dui. Ten einde die vloeibaarheid van die elemente, die verhouding tussen God en mens, asook die mens (Neoplatonies) terugkerend na God aan te dui, begrond Mechtild die harmonie en integrasie van die kosmos nie in statiese vasstaandes of digthede nie, maar in beweging - beweging is vir haar die teken van syn, leween gees. Dieelemente word deurbeweging getransformeer vanaf 'swaarheid, onbeweeglikheid en nie-syn na ligtheid, beweging en syn' (Franklin 1978:160), waar beide God en die siel deur 'n reeks van onsigbaar beweeglike oorgange tot uiteindelike eenwording vorder.

\section{Pseudo-Dionisius (1990: De mystica theologia I.2,1000B; V,1048B). \\ 10.Pseudo-Dionisius (1990: De Divinis nominibus I.5,593 AB; I.5,593D; I.6,596A; De coelesti hierarchia IV.1,177D).}

11.Pseudo-Dionisius (1990: De Divinis nominibus V.4,817C,817D). 
Die bewegende siel kom uiteindelik tot rus in die bewegende God: hierin is ook 'n duidelike Augustiniaanse tema werksaam, van liefde as die siel se 'gewig', wat dit trek na die natuurlike rusplek daarvan in God (Gilson 1960:134-62). Die opvatting van 'onbeweegde beweging' of 'vlietendheid' as metafisiese kernbegrip, maak Mechtild sowel van toepassing op die verhouding tussen die Persone in die Drie-Eenheid (met nadruk op die Niceense begrip 'uitgaan'), as die oorsaak van die eenwordende liefde en vreugde tussen die menslike siel en God. Sy vind ook die vervulling van die siel en die diepste wese van God nie in 'n statiese toestand nie, maar in handeling: Die siel kom nie staties tot vervulling nie, maar handelend, 'synend' - en God is liefde daar waar God sy liefde doen (of God se liefde gedoen word). Weer is die klem op beweging en nie ' $n$ toestand nie.

\section{Emanasie en antroposentrisme}

Trouens, Mechtild is minder geïnteresseerd in skepping en kosmologie as wat sy in herskepping is, ook wanneer sy Neoplatoniese emanasie in gedagte het: die morele dimensie gaan by haar die metafisiese dimensie vooraf; eers die werkwoord, dan die selfstandige naamwoord. So 'n bewegende kosmos is natuurlik minder ordelik en meer antroposentries as wat die klassieke, meer essensialistiese of intellektualistiese weergawes van emanasie bereid sou wees om toe te gee. Vir Mechthild (1980:2:22:42; sien 3:1:55) ${ }^{12}$ is die mens bo die engele verhewe, maagde langs die moeder Maria en Johannes die Doper en die apostels, langs (en nie benede nie) die serafim. Met inbegrip van hulle geestelike natuur en onvergelyklike intellek, is die engele inderwaarheid 'n minder glorieryke spieëlbeeld van die Goddelike natuur as die mens self, aangesien die engele nie die menslikheid van Christus of die mens, en daarmee saam, die liefde en gelyklopende lyding van Christus en die mens deel nie (1980:2:3:29; 4:14:107).

Sy gaan selfs verder in hierdie unieke bewegingsmatige antroposentrisme deur God self eerder te beskryf in terme van handelende liefde ('God is liefde', 1 Joh 4:8; 'So sal God alles wees vir alles', 1 Korintiërs 15:28), as met die statiese Hebreeuse frasering Jahwe, 'Ek is wat Ek is' - God is nie bloot wat God is nie, vir Mechtild is dit, op die spoor van Abelardus se Megariaanse argument (sien Beukes 2011), God doen wat God wel doen en God kan net doen wat God wel doen. God is aan die beweeg deur die skepping, oral gelyk teenwoordig, kenbaar vanuit die liefdevolle, menslike siel. God skep die menslike siel uit sowel die liefde vir God se eie vooreksistente menslikheid (in die tweede Persoon) as die individuele menslike siel. God se verlange na die siel is grensloos; die liefde dryf God selfs om 'die menslike siel te dien'. Dramaties en oorspanne soos wat dit moontlik kan aandoen, verantwoord Mechthild (1980:1:23:11-3) dadelik dat hierdie stelling die orde van die Goddelike en die menslike nie ondermyn nie, aangesien dit God se eerste natuur is om lief te hê (en sy stel dit innig met gebruik van die Duitse

12.Ek werk vanuit die Duitse teks en lys die uitstekende vertaling van Mesch (Mechtild 1991) vir eksterne kontroledoeleindes. Verwysings na Das fließende Licht der Gottheit (fLG; Mechthild 1980) word hierna per boek, hoofstuk en bladsynommer aangedui. werkwoord minnen) en deur die mens se siel so te bemin, God gehoorsaam is aan net God self. Skepping na die beeld van God is 'n skepping in liefde ter wille van die beweging van liefde, ter wille van die werkwoord liefhê. Natuurlik is dit 'n kontroversiële posisie wat kort nadat fLG begin het om in die Duitse volkstaal te sirkuleer in die laat 1250's, hewig gekritiseer is. Mechtild antisipeer egter hierdie kritiek en verdedig haar vermindering van die ewige afstand tussen God en mens op grond van sowel God se liefde, as die mens se liefde, deur telkens te benadruk dat 'slegs omdat die skepsel self kan liefhê, kan daar gedeelde terrein tussen God en mens wees' (bv. 1980:1:44:21,1:39:18,2:3:27,6:1:174). Alleen omdat dit in die aard van die skepsel is om (God) lief te (kan) hê (sy beweeg nie algeheel verby die mens se roekelose selfvervreemding van God nie), is die terugkerende eenwording met God in reditus moontlik.

\section{Genuanseerde epistemologie}

Dit is binne die raamwerk van 'n Neoplatoniese kosmos, saamgestel uit en georden deur vervlietende beweging en liefde, met die aktiewe eenwording van die menslike en die Goddelike as die natuurlike en wedersydse oogmerk van God en mens, dat Mechtild se aardse antropologie ontvou. Hoewel die fisiese wêreld vir haar ' $n$ plek vol versoekings is wat bogenoemde oogmerk voortdurend uitdaag, neem sy haar voor om 'die wêreld nie te spot nie' (1980:1:2:5, 3:5:66). In ooreenstemming met haar Middeleeuse voor- en medegangers se aversie aan die wêreld, gebruik sy nietemin dikwels ekstreem afwysende taal wanneer sy oor die wêreld praat, as 'stof', 'vuil' en die liggaam as die 'vyand' en 'kerker' van die siel (bv. 1980:4:2:94, 5:22.145). Tog onderbreek sy hierdie afwysinge deur prakties oor die liggaam se behoeftes te praat, insluitende die aptyte, en wys dat die 'korrupsie van dinge' in sonde (vir haar beteken dit die afstanddoening van die verhoudingsmoontlikheid tussen mens en God) tot uitdrukking gebring word, en nie in die wêreld of materie as sodanig nie (bv. 1980:1:3:6, 1:46:24, 2:25:49; 3:1:88). Die liggaam kan moontlik selfs 'n instrument vir verlossing wees, wanneer dit positief gebruik word om die spontane wil te oorkom (wat sy in die moderne Duitse vertaling Selbstwille $e^{13}$ of 'self-wil' noem), of dit in die gees of die liggaam self, tot uitdrukking gebring word: boonop argumenteer sy in die kenmerkende styl van die begyne, is dit deur die liggaam wat die deugde beoefen word, goeie werke gedoen word en dat daar wel miskien meriete kan wees, watter sprake daar ook al van meriete in hierdie verband kan wees, in die tegnies instrumentele sin van liggaamlike barmhartigheid: om 'jou liggaam en beweging uit te leen vir 'n ander' (of 'brood moet aangedra word, dit kom nie vanself by die verhongerdes uit nie', 1980:5:22:145; sien ook 6:6:180, 6:15:189, 6:26:201). Mechtild se spekulatiewe en affektiewe werk het gepoog om die ervaring en 'n sin vir algehele toewyding aan die transendente, met filosofiese refleksie te integreer. Daarin blyk dit dat die wêreld altyd weer té aangrypend is om bespot te word. Dat die wêreld met filosofiese insig geag

13.'Self-wil' kom vir Mechtild aan op eliminering van die psigologiese fakulteit van die wil (hetsy superieur tot of ondergeskik aan die intellek), sonder dat sy die intellek daarmee tot superieur tot die wilsmatige verhef. 
word nié bespotlik te wees nie, vind ons in haar implisiete werksbegrip: 'Maak die wêreld nie tot bespotting nie'.

Hierdie begrip word uitgedruk deur 'n opvattting van liefde as die 'struktuur van die teenswoordige wêreld' waarmee 'hierdie wêreld self geag en benader behoort te word' (1980:121; 142; 225) omdat 'God dan self daarmee in liefde benader word' (1980:27; 31; 114). Nog duideliker stel sy (1980):

Onder die enorme druk van liefde, verloor sy haarself. In hierdie mees verblindende lig word sy blind in haarself. En in hierdie algehele blindheid sien sy die duidelikste dat die wêreld uit liefde nie bespot moet word nie. (p. 22)

Dan eers (1980:29) 'sien en smaak 'n mens dat die Godheid vloei'. 'n Mens sien die helderste wanneer jy blind geword het vir die materialisme van die wêreld en daarom die aangrypende ander kwaliteite van hierdie wêreld as die materiële kan waarneem.

Vanuit hierdie verblindende helderheid en heldere verblindheid vir die wêreld, waardeer Mechtild die sintuie positief binne ' $n$ epistemologiese konteks. Hoewel sy opmerk dat haar eie mistiese en visioenêre ervarings van algemene ervarings verskil, gebruik sy meer gereeld die algemene sintuiglike ervaring van die werklikheid as ' $\mathrm{n}$ bron van kennis oor God (1980:6:31:205). Sy is nie tegnies Aristoteliaans, soos die skolastici van haar tyd, besig om die ervaring te ontleed nie, maar spits haar daarop toe om die verband tussen sintuiglike en intellektuele kennis te verduidelik. ${ }^{14}$ Sy vermeng hierdie twee kategorieë (wat in die Middeleeue normaalweg streng van mekaar onderskei is) met treffende geloofwaardigheid: ervaring kan volgens Mechtild nooit afsonderlik hanteer word as juis die rol wat dit binne 'n geordende epistemologie speel nie. Met 'geordende epistemologie' word bedoel dat kennis 'georden' is solank dit tot die realisering van 'n pertinente oogmerk meewerk en dat kennis nagejaag word ter wille van daardie realisering. Enige nie-teleologiese opvatting van kennis laat Mechtild koud: sy beskou filosofie ter wille van filosofie (ook teologie ter wille van teologie) as 'goddelose selfkoestering' (1980:6:31:205, 2:3:28, 6:4:179). Asketiese praktyke, onder meer selfflagellantisme, wat wyd in die bedelordes beoefen is en waaraan Mechtild haar gereeld onderwerp het, 'suiwer die sintuie' en skerp die rede op 'om te onderskei die dinge waarop dit werklik aankom' (1980:5:4:131). Die mens het die verantwoordelikheid om die sintuie en die rede sodanig op te voed, terwyl die gesuiwerde ervaring van God (in die sin dat die liggaam asketies gedissiplineer is) kan lei tot verligting van die rede en tegelyk verdieping van die sintuiglike belewing van die leefwêreld.

Die sintuie onderskei deur die ervaring objekte van mekaar en ontwikkel voorkeure op grond van daardie onderskeiding in verhouding tot mekaar. Mechtild werk dus met 'n aktiewe

14. Mechtild staan agterdogtis teenoor filosofie in hetsy binne die kerklik gesanksioneerde, teologiese fakulteite van die opkomende universiteite, hetsy bine die kloosterskole en katedralskole wat onder die to van van die plaaslike abdye geval het. In daardie opsig adem sy dieselfde suspisi teenoor filosofie wat in die middel van die 11de eeu in Frankryk onder leiding van figure soos Petrus Damianus (1007-1072) wyd verspreid was (sien Beukes 2019a). intellek: die sintuie opereer intensioneel en sy ontwikkel daarmee die volle skopus van die moderne Duitse vertaling van Sinne (waarmee sy na die fakulteite van die ervaring, sowel as waarneming as sodanig, na idees in die bewussyn, na betekenis, na verstaan en na rasionele kennis self verwys). Daarby voeg sy haar unieke opvatting van die 'geestelike sintuie', waarmee sy in gedagte het kennis van die Goddelike, na analogie van die wyse waarop die fisieke sintuie die ervaring voed, met daardie hele skopus van betekenisse wat sy in terme van Sinne daartoe voeg (1980:6:31:205). In die funksionering van beide die fisieke sintuie en die 'geestelike sintuie', is daar elemente van begeerte en die versterking van sensuele plesier, terwyl die geestelike ervaring 'n 'hoër perspektief' bied, wat die evaluerende rol van die fisieke sintuie 'gelyktydig uitbrei en oorstyg' (1980:5:22:146). Vanuit die klem op die funksies van die aktiewe intellek is Mechtild se kennisbegrip dus prakties, selfs tot dié mate dat 'n kontemplatiewe lewe vir haar beteken dat die deugde prakties in goeie werke moet realiseer.

\section{Die driedelige verhouding tussen die siel en die sintuie}

Die tersaaklike onderskeid vir Mechtild is dus nie tussen praktiese en teoretiese of materiële en nie-materiële kennis nie, maar tussen kennis van die menslike en die Goddelike. Sowel die kennis van die menslike as die Goddelike beskik vir haar oor ' $n$ sintuiglike en ' $n$ intellektuele komponent. Alhoewel die passiewe, materiële liggaam en die aktiewe nie-materiële siel fundamenteel verskil en in die teenswoordige lewe op verskillende wyses vervulling vind, word die twee intiem verenig in die sintuie, wat materieel, maar ook aktief en intensioneel opereer (1980:2:1:26, 2:22:42). Alle natuurlik verworwe menslike kennis, met inbegrip van die uitkomste van rasionele afleiding of inferensie, word volgens Mechtild deur die sintuie verwerk en hoort tot die sintuiglike werklikheid (1980:2:23:44, 5:2:130). Sy staan agterdogtig teenoor abstrahering en abstrakte argument, aangesien dit 'wegdwaal van die noodsaaklike korrektief van lyding soos deur die sintuie ervaar en verwerk is en blootgestel is aan verdere dwaling deur intellektuele hubris' (1980:5:4:131, ook 7:8:227 [waar Mechtild die reis na God deur lyding, deug, kennis en liefde beskryf]). God spreek die siel deur die sintuie aan, en menslike liefde (as keuse vanuit die vrye wil) neem vertrek vanuit die sintuie en kom vanuit die sintuie in die siel tot wasdom, antwoordend tot God (1980:5:4:131, 6:23:200, 6:31:205). Die siel lei dus die sintuie, wat die siel as't ware van kennis bedien, en tog is die siel en die sintuie voortdurend van mekaar bewus (1980:6:26:201, $1: 26: 14)$

Mechtild spel hierdie wesenlike verhouding tussen die siel en die sintuie in drie belangrike dialoë uit, waarin die individuele of persoonlike siel en die sintuie, die siel en die verstaanshandeling, en die bewussyn en die verstaanshandeling, tot uitdrukking gebring word. In die eerste dialoog tussen die siel en die sintuie, met verwysing na die verhouding tussen die persoonlike siel en die 
sintuie, word die siel tot die stappe van vervulling deur die sintuie aangespoor, hoewel die siel terselfdertyd 'vooruit vlieg' en die sintuie nie in staat is om die siel in die opstygend emanasionele eenwording met die Godheid te volg nie. Die siel troos die sintuie daarmee dat sy die sintuie steeds sal benodig 'wanneer sy eenmaal terugkom' (1980:1:44:18). In die tweede dialoog word die verstaanshandeling aangebied as 'uiteindelik wyser as die eenvoudige siel', maar nie in staat om die siel self te volg in die siel se reis deur liefde nie. Daar plof die verstaanshandeling ineen: die verstaanshandeling herken die siel as 'beeld van God', maar kan die misterie van die eenwording tussen God en die siel nie penetreer en uiteindelik verstaan nie (1980:2:19:38). Wat bly dan oor in die verstaanshandeling as daar niks meer is om te verstaan nie? In die derde dialoog bevestig die verstaanshandeling opnuut die herkenning van die siel as die 'beeld van God', maar kan (weer) nie die vraag beantwoord waarom die siel vanuit die spontane natuur daarvan, nie self in staat is tot eenwording met die Godheid nie. Begelei deur die superieure perspektief van die bewussyn, begryp die ingeplofte verstaanshandeling uiteindelik dat 'n aktiewe beeld tekortskiet, naamlik die beeld van 'goeie werke wat liefde in beweging is' (1980:7:17:232). Met ander woorde: deur die geestelike bewussyn word die verstaanshandeling begelei om te verstaan dat dit nie verstaan nie. Mechtild sluit hierdie drie aangrypende dialoë af met twee kort gedigte, waarin die tema gevier word van 'die vrugbare vereniging van kennis en liefde in die wysheid van die sintuie begin' (1980:5:11:139, 7:43:257).

\section{Die interafhanklikheid van die vorme van kennis}

Mechtild maak dus die leer van die radikale interafhanklikheid van fisieke, intellektuele en geestelike kennis oop, terwyl sy verseg om intellektuele kennis van sintuiglike kennis te skei, of die kennende subjek van die kennende objek los te maak. Sy beskou die sintuie as kognitiewe elemente met 'n enorme vermoë, selfs om na God heen te reik. Die sintuie verteenwoordig die, volgens haar, vernaamste voorwaarde vir die beliggaamde lewe, wat teenswoordig sowel 'n vleeslike as vergeestelikte vorm aanneem. Wanneer die beliggaamde lewe (deur die dood) 'uiteindelik begenadig' word, 'neem die sintuie deel aan die vergoddeliking van die siel deur die opstygende eenwording met God' (1980:4:14:107). Volgens Mechtild is die uiteindelik enigste werklik betekenisvolle vorm van kennis die kennis wat tot uitdrukking kom in die eenwording met God, in die ervaring van God wat die enigste ervaring is vir 'blywende verstaan' (1980:1:44:20, 4:23:118). Die verstaan van die Goddelike is nie die resultaat van abstrahering of abstrakte intellektualisering nie ('n punt waarop feitlik elke vroeë skolastikus met haar sou verskil). Die verstaan van die Goddelike vind volgens haar plaas in die siel se transendering van die sintuie, wanneer dit ineens ook intellektuele herkenning transendeer - wat daarop volg, is in terme van die ervaring onverwoordbaar.
Die uiters begrensde rol wat Mechtild aan abstrakte kennis toeken, korrespondeer met haar beskouing oor die ware objek van menslike kennis, naamlik 'God wat geleef en gely het vir liefde'. Vir haar impliseer 'kennis van die rasionele feite' kennis van Goddelike liefde, die psigologie en ambivalensie van die menslike wil, en wispelteurige menslike liefde, wat nietemin 'n 'vooraanskouing' van God se liefde is (1980:4:23:119). Waar twee mense mekaar liefhet, is daar wel die vooraanskouing van die liefde van God. Waar'n gemeenskap van mense mekaar liefhet, is dit die belewenis van die liefde van God. Waar die wêreld God liefhet, is dit die realisering van die liefde van God self. Mechtild aanvaar, selfs vanuit haar beperkte13deeeuse sosio-kosmologiese verwysingsraamwerk, dat laasgenoemde 'altyd uitstaande' sal wees. Die hoogste intellektuele toestand is daarom uiteindelik net verwondering oor die wonder van Goddelike liefde en die hoogste oogmerk van die menslike bestaan in die beoefening van die deugde, in bewegende antwoord op daardie liefde.

\section{Die etiek van sorg uit liefde vir die Ander}

Mechtild se etiek tree na vore vanuit haar nadruk op die ervaring van liefde. Omdat die siel self 'n 'beeld' is, vertoon die siel 'n spontane en natuurlike inklinasie na die ware objek daarvan - God se liefde - tensy dit verblind is deur Selbstwille. Sy staan soos Salisbury (ca.1115-1180) ${ }^{15}$ in die Christelik Middeleeuse vryheidstradisie, wat beteken dat sy nie gepreokkupeerd is met die grense van toelaatbare handelinge of die ontleding van verpligtinge nie. Daarom bied sy ook geen advies aan ten opsigte van konflikterende verpligtinge nie. Sy verbind die deugde in soverre elke deug in verband met liefde gebring kan word, waaruit opvattinge na vore tree soos dat 'uit klein oortredinge kom wel groot sondes na vore', 'gehoorsaamheid ${ }^{16}$ en dankbaarheid is die hoekstene van deug' en 'self-wil is die grootste ondeug' (1980:6:19:196, 5:5:134, 6:7:182). Haar vernaamste etiese interesse is juis die private deugde, vanuit die enkeling se private verbintenis met God, wat die openheid en toeganklikheid van die individuele siel in nadering tot God verhoog.

Vanuit die Middeleeuse tradisie van Christelike vryheid, wat slegs buite die kloosterwese gefloreer het, plaas Salisbury kenmerkend (en Aristotelies) klem op 'matigheid'. Matigheid of die 'goue middeweg' is die strukturele eienskap van alle deugde waarmee 'n individu moontlik toebedeel kan wees: deugde soos dapperheid en die soeke na geregtigheid is as't ware middelpunte tussen ondeugde, soos oordaad of luiheid.

15.Gibson (1989:118) dui oortuigend aan dat Salisbury, Pseudo-Dionisius, Albertus Magnus en Hildegard, onder Mechtild se belangrikste invloede tel: waarskynlik omdat Salisbury self nie ' $n$ kerklike ampsdraer of geordende monnik was of wou wees nie.

16. Let daarop dat 'gehoorsaamheid' vanuit die bedelordes en juis by Mechtild ' $n$ ander betekenis gehad het as die soort betekenisse wat tydgenootlike en vora voorafgaande kloosterskrywers in gedagte gehad het. Vir die kloosterskrywers beteken 'gehoorsaamheid' in die eerste plek'n dienstigheid en gehoorsaamheid an die onmiddellike kloostersenior. Die orde in die kloosters was van hierdie en subordinerende premisse afhanklik. Vir Mechtild beteke 'gehoorsaamheid', bykans libertyns, gehoorsaamheid aan God alleen en verantwoordelikheid teenoor God alleen, met verbygaan van enige kerklike of opsighoudende struktuur. 
Daarom moet die ondeugde self gebalanseerd geweeg word: bepaalde aktiwiteite soos jag, banketvieringe, seksuele aktiwiteit en alkoholgebruik is volgens Salisbury nie per definisie afwysbaar nie, maar moet in terme van reëlmaat en intensiteit geweeg word: solank as wat dit nie 'n oordrewe gewoonte is, of telkens met oordaad gepaardgaan nie, is dit aanvaarbaar. Matigheid is 'n etiese geleier en die basis vir 'n eties verantwoorde en gelukkige lewe. So moet die koning ook wees: iemand wat mag matig uitoefen, wat sy onderdane nie enersyds oorlaat aan hulle diskresies en drifte nie, maar wat andersyds nie so beheersugtig optree dat die onderdane se vermoë tot die uitoefening van vrye wil aan bande gelê word nie. Koninklike matigheid is die ekwivalent van die respek vir die ware sfeer van individuele vryheid, waartoe elke lid van die politieke gemeenskap toegang behoort te hê. Selfs die oordadige soeke na deug kan in hierdie sin ondeugsaam wees: wanneer die koning oormatig klem plaas op die deug van sy onderdane, kom dit op ondermyning van gematigde regering neer. Die koning behoort aan die onderdane genoegsame persoonlike vryheid te verleen, juis sodat hulle kan fouteer en daaruit kan leer, solank as wat die foute wat die onderdane maak, nie die wesensinhoude van die Christelike geloof ondermyn of die veiligheid van die politieke gemeenskap, in gevaar stel nie. Trouens, die vermoë van die individu om die deugde aan te leer, is afhanklik van die moontlikheid om daarin te faal (Beukes 2019d).

Dit was 'n werklik unieke polities etiese posisie in die $12 \mathrm{de}$ eeu en aspekte van Mechtild se etiek in die onwilligheid om streng kategorieë vir die deugde en morele gedrag op te stel, sluit hierby aan. Seksuele kuisheid is wel 'n deug, soos wat die kloosterskrywers inderdaad altyd aangedring het, maar by Mechtild is dit nie ' $n$ problematiese kwessie nie, aangesien sy alle erotiese en libidinale energie na God self projekteer ('Die siel is God se vriend, beminde en huisvrou'; vgl. 1980:3:1:59, 4:14:108). Sy waardeer kuisheid andersins positief as 'n teken van toewyding, eerder as 'n stryd teen versoeking en vermorsing. Daarom was haar hantering van ongelukkig getroude, vervreemde en geskeide vroue, asook weduwees, deurgaans sagsinnig - in teenstelling met die oorwegend misoginistiese houding in veral die 12de en 13de eeue teenoor enkellewende vroue (sien Eliass 1995:14).

Hoewel Mechtild vanuit haar implisiete werksbegrip ('Maak die wêreld nie tot bespotting nie') belang het by en inderdaad belangstel in die sekulêre wêreld (anders as by verre die meeste kloostergangers van haar tyd, wat onteenseglik 'uit die wêreld' wou wees), beweeg sy nie oor tot 'n maatskaplike en politieke analise van die onrustige Duitse kultuurlandskap van die 13de eeu nie. Sy maak egter 'n punt daarvan om politieke mag herhaaldelik as " $n$ hindernis tot ' $n$ vervulde en morele lewe' te tipeer (bv. 1980:6:1:171, 4:17:110, 3:21:86, 4:17:110, 5:35:169). Onverbloemd krities teenoor veral manlike gesagstrukture in die kloosters en die kerk van die 13de eeu, verleng sy daardie kritiek onvoorwaardelik na die politieke sfeer. Daarom dien dit volgens Mechtild 'geen doel meer' om, eie aan die vroeë skolastiek, met 'n tabel (Figuur 1) van deugde te werk, soos wat dit deur, onder andere, die 12de- eeuse Hildegard ${ }^{17}$ grondig uitgestal word nie. In stede daarvan om met so 'n tabel te werk, herlei sy daarom alle sosiale deugde na 'diens in liefde en liefde deur diens', wat na haar mening steeds korrespondeer met die feodale stelsel se diepste konsoliderende ideale (1980:6:1:171).

Sosiale verhoudinge word ten beste gereguleer deur die deugde wat 'n 'alledaagse bestaan in die nabyheid van die Ander' moontlik maak; daarom plaas Mechtild wel klem op deugde soos medelye, barmhartigheid, opgewektheid, gesonde oordeel, sagsinnigheid, geduld, diensbaarheid en beskeidenheid (1980:5:23:151, 6:1:171). Hierdie ingeoefende eienskappe - want vir Mechtild is geen deug 'n spontane eienskap nie - lei tot die goeie werke wat erns met die wêreld bevestig en is die stempel van haar oproep tot haarself en haar medegangers om die 'wêreld nie tot bespotting te maak nie'. Anders gestel: die etiek van deugde neem die wêreld ernstig op, sonder dat die deugde geskematiseer hoef te word. Hierdie deugde of ingeoefende eienskappe korrespondeer wel met die werke van selfopgelegde afsondering, gereelde vas en selfdissipline, soos in die kloosterwese met nadruk geïstitusionaliseer, maar dit komplementeer juis die bedelordes se direkte ingrepe in en betrokkenheid by die wêreld, die uitreik na die blootgestelde Ander (juis deur mense wat self institusioneel en maatskaplik blootgestel is), die versorging van die afgetakeldes en die voeding van die verhongerdes - en, belangrik, selfs die 'stilstand by neerslagtiges' of psigologies gepynigdes (1980:5:22:146, 5:23:151, 6:1:172, 7:2:221).

\section{Slot}

Mechtild von Magdeburg verteenwoordig 'n sonderlinge kultuurkritiese stem vanuit die 13de eeu. Haar filosofiese perspektiewe verteenwoordig 'n metafisika, epistemologie en etiese psigologie van liefde, wat die wêreld konstant ernstig opneem. Haar nadruk op die vereniging van die menslike en die Goddelike, die primêre rol van die ervaring in kennisverwerwing en die belang by die Ander in ' $n$ gebroke wêreld, staan alles ten dienste van haar indruk dat liefde die heersende beginsel van God en God se skepping is. Met weinig belangstelling in essensialistiese of kousale ontledings - uitgeslote die beginsel van liefde - en met weinig gemeen met haar vroeë skolastiese medegangers se intellektuele verfyning van die leefwêreld (weliswaar sonder om in hulle fyn mantels by daardie verfynde wêreld betrokke te raak), het Mechtild wel invloed uitgeoefen op die mistiese trajekte van die latere Middeleeue, in besonder op die Duitse trajek van Meister Eckhart in die volgende eeu.

Mechtild was so onfilosofies vir haar eie tyd as wat sy filosofies vir alle tye is: haar spekulatiewe werk het gepoog om die ervaring en 'n sin vir algehele toewyding aan die transendente, met filosofiese refleksie te integreer. Daarin blyk dit dat die

17.Vergelyk byvoorbeeld hierdie deel uit 'n lang tabel in Hildegard se tweede werk in haar trilogie Vitae meritorum, waarvan die bron die vierde-eeuse digter Prudentius haar trilogie, Vitae meritorum, waarvan die bron die vierde-eeuse digter Prudentius se Psychomachia was, waarin deugde en ondeugde tabelmatig en diskursie teenoor mekaar opgestel is. Die Middeleeuse etiek is deur hierdie werk grondig geïnspireer, soos wat blyk uit die veelheid van sodanige etiese tabelle in die skolastiese periodes as sodanig. Aangrypend soos wat hierdie tabelle opval, is Mechtild geensins daarin geïnteresseerd nie, hoewel sy sonder enige twyfe toegang tot Hildegard se volledige korpus gehad het (sien Beukes 2019c:12). 


\begin{tabular}{|c|c|c|c|}
\hline Inepta laetitia & Vergryp, oordaad (sinlik, seksueel) & Gemitus ad Deum & Intense (fisieke) verlange na God \\
\hline Ingluvies ventri & $\begin{array}{l}\text { Toegewing aan (seksuele en sinlike) } \\
\text { impulse }\end{array}$ & Abstinentia & $\begin{array}{l}\text { Onthouding (van seksuele en sinlike } \\
\text { impulse) }\end{array}$ \\
\hline Acerbitas & Suinigheid, bruuskheid & Vera largitas & $\begin{array}{l}\text { Vrygewigheid, openheid (vir die Ander } \\
\text { se belange) }\end{array}$ \\
\hline Impietas & $\begin{array}{l}\text { Gebrek aan vroomheid } \\
\text { (onverantwoorde ondeug) }\end{array}$ & Pietas & Vroomheid (verantwoorde deug) \\
\hline Fallacitas & $\begin{array}{l}\text { Bedrog, leuens, misleiding, (seksuele) } \\
\text { ontrou }\end{array}$ & Veritas & $\begin{array}{l}\text { Waarheid (altyd in staat om objektief } \\
\text { te verantwoord) }\end{array}$ \\
\hline Contentio & Uitdagende lewenshouding & Pax & Vredeliewende lewenshouding \\
\hline Infelicitas & $\begin{array}{l}\text { Selfkoesterende melancholie } \\
\text { (Weltschmerz) }\end{array}$ & Beautitudo & $\begin{array}{l}\text { Altyd gereed om die skone nie-terloops } \\
\text { te herken }\end{array}$ \\
\hline Immoderatio & 'n Gebrek aan gebalanseerde matigheid & Discretio & $\begin{array}{l}\text { 'n Bewuste keuse van gebalanseerde } \\
\text { matigheid }\end{array}$ \\
\hline Perditio animarum & Onredelike onoortuigbaarheid & Salvatio animarum & $\begin{array}{l}\text { Verlossing van die siel (vanuit redelike } \\
\text { oortuigbaarheid) }\end{array}$ \\
\hline Superbia & Hoogmoed (afwysing van die Ander) & Humilitas & $\begin{array}{l}\text { Beskeidenheid (gelykheid met } \\
\text { die Ander) }\end{array}$ \\
\hline Invidia & Jaloesie (opeising van die Ander) & Charitas & Mededeelsaamheid (sorg vir die Ander) \\
\hline
\end{tabular}

Bron: Beukes, J., 2019c, 'Hildegard von Bingen as 'n 12de-eeuse filosoof-teoloog', Litnet Akademies 16(1), pp. 83-85. https://www.litnet.co.za/hildegard-von-bingen-1098-1179-as-n-12de-eeusefilosoof-teoloog/.

FIGUUR 1: 'n Uittreksel uit Hildegard von Bingen se tabel van ondeugde en deugde.

wêreld altyd weer té aangrypend is om bespot te word. Dat die wêreld met filosofiese insig geag word nié bespotlik te wees nie, is die tydlose filosofiese geskenk vanuit die eelterige hande van 'n blinde, wyse begyn.

Ut enim monachōrum opera legerem, necesse erat mē ipsum monachum fierī.

\section{Erkenning \\ Mededingende belange}

Die outeur verklaar dat hy geen finansiële of persoonlike verbintenis het met enige party wat hom nadelig kon beïnvloed in die skryf van hierdie artikel nie.

\section{Outeursbydrae}

J.B. was die enigste outeur betrokke by die skryf van die artikel.

\section{Etiese oorwegings}

Hierdie artikel volg alle etiese standaarde vir navorsing sonder direkte kontak met mens of dier.

\section{Befondsing}

Befondsing is verskaf deur die Departement Filosofie, Fakulteit Geesteswetenskappe, Universiteit van die Vrystaat.

\section{Data beskikbaarheidsverklaring}

Data-deling is nie van toepassing op hierdie artikel nie, aangesien geen nuwe data in hierdie studie geskep of ontleed is nie.

\section{Vrywaring}

Die outeur verklaar dat standpunte ingeneem die outeur se eie standpunte is en nie die standpunte van enige institusie of organisasie reflekteer nie.

\section{Literatuurverwyings}

Beukes, J., 2011, 'God kan net doen wat God wel doen: Petrus Abelardus se Megariaanse argument in Theologia scholarium, Opera Theologia III', HTS Teologiese Studies/ Theological Studies 67(3), Art. \#883, 1544-1555. https://doi.org/10.4102/hts.v67i1.883

Beukes, J., 2019a, (in publikasie), "“Foucault se sodomiet”: Damianus se Liber gomorrhianus (1049) heropen', HTS Teologiese Studies/Theological Studies, Art. \#5216.

Beukes, J., 2019b, (in publikasie), 'Héloïse d'Argenteuil se filosofiese uitset', HTS Teologiese Studies/Theological Studies, Art. \#5281.

Beukes, J., 2019c, 'Hildegard von Bingen as 'n 12de-eeuse filosoof-teoloog', Litnet Akademies 16(1), pp. 64-102. https://www.litnet.co.za/hildegard-von-bingen1098-1179-as-n-12de-eeuse-filosoof-teoloog/.

Beukes, J., 2019d, 'Policraticus en Metalogicon: 'n Bywerking van die Saresberiensisnavorsing, 2013 - 2018', Verbum et Ecclesia, 40(1). https://doi.org/10.4102/ve. v40i1.1959

Bynum, C.W., 1984, Jesus as mother. Studies in the spirituality of the high Middle Ages, University of California Press, Los Angeles, CA.

Dickens, A.J., 2009, The female mystic. Great women thinkers of the Middle Ages, I.B. Tauris, London.

Dronke, P., 1984. Women writers of the Middle Ages: A critical study of texts from Perpetua to Marguerite Porete, Cambridge University Press, Cambridge.

Eckenstein, L., 2010, Woman under monasticism. Chapters on Saint-Lore and convent life between A.D. 500 and A.D. 1500, Theophania, Calgary.

Eliass, C., 1995, Die Frau ist die Quelle der Weisheit. Weibliches Selbstverständnis in der Frauenmystik des 12. und 13. Jahrhunderts, Centaurus Verlag, Pfaffenweiler.

Franklin, J.C., 1978, Mystical transformations. The imagery of liquids in Mechthild von Magdeburg, Fairleigh Dickinson University Press, Madison, NJ.

Gibson, J, 1989, Mechtild of Magdeburg, in M.E. Waithe (ed.), 1989, A history of women philosophers. Volume II. Medieval, renaissance and enlightenment women philosophers, Kluwer, Dordrecht, pp. 115-140.

Gilson, E., 1960, The Christian philosophy of St Augustine, (transl.), L.E.M. Lynch, Random House, New York.

Howard, J., 1984, 'The German mystic Mechthild of Magdeburg', in Wilson (ed.), University of Georgia Press, Athens. pp. 153-163.

Lewis, G.J., 1989, Bibliographie zur deutschen Frauenmystik des Mittelalters, Erich Schmidt Verlag, Berlyn.

McDonnell, E.W., 1954, The beguines and beghards in Medieval culture, Rutgers University Press, New Brunswick, NJ.

McGowin, E.H., 2011, 'Eroticism and pain in Mechtild of Magdeburg's The flowing light', New Blackfriars 92/1041, pp. 607-622. https://doi.org/10.1111/j.17412005.2010.01392.x

Mechtild, 1980, Offenbarungen der Schwester Mechthild von Magdeburg oder das fließende Licht der Gottheit, in P. Gall Morel (Red.), Wissenschaftliche Buchgesellschaft, Darmstadt.

Mechtild, 1991, The flowing light of the divinity, in S. Clark (introduction and ed.) \& C. Mesch (transl.), Garland, New York.

Pseudo-Dionisius, 1990, Corpus Dionysiacum, B.R. Suchla, G. Heil \& A.M. Ritter (eds.), Walter De Gruyter, Berlin 